\title{
Urban Space and the Power of Place: Past Practices and Thoughts for the Future
}

\author{
KEN HAMPSON and JUDITH ROBERTS \\ Institute of Advanced Architectural Studies, University of York \\ United Kingdom
}

\section{HISTORIC TOWNS AND A SENSE OF PLACE}

A 'sense of place' is both a powerful draw to and a clear indicator of an historic environment. The feel of the place in particular, is one of the senses we have of an historic town or city. We sense 'place' and 'local distinctiveness' through the nature, shape, quality and materials of the buildings and from the spaces. We sense place from the evidence of human use and activity in the past and in the present.

A living historic environment is a continuum, a process. An historic town is a context where people can connect with the past and look to the future as well as function in the present. This paper examines the way in which 'conservation' has been practised within the historic urban environments in England and Wales. [The paper concentrates on these areas since Scotland and Northern Ireland have their own systems and procedures. ]. The paper will examine the historical influences which underlie the conservation awareness in this country and will ask how successful the established conservation approach has been in conserving the character of historic towns and will look at present issues and future directions.

\section{THE CHARACTERISTICS OF AN HISTORIC TOWN}

First let us examine a little more closely what we mean by 'historic town or city'. What are the essential characteristics we are seeking or have sought to protect and conserve?

An historic urban environment is a living organism; it is an environment where the physical fabric of the old is seen to be co-existing in productive harmony with the new. In such a town contemporary society has the opportunity to invest the place with its own memories in a seamless continuum with its predecessors. What we look at in an historic town, what we appreciate and indeed what we sometimes travel thousands of miles to see, is a process, it is the continuing interaction of a related sequence of life and living cycles. It is a dynamic entity. The human life cycle is frequently the shortest. In the past people have worked, created and died and in the course of this process have thrown up buildings and spaces which reflect their occupations and their aspirations. These buildings and spaces in turn take on a life cycle of their own; some are re-inhabited by other generations, some are lost, some are partially destroyed and reused. This is a natural process which creates and throws off successive skins; loss is part of the process, loss is part of regeneration. One of the most important characteristics, indeed a requirement, of a living historic environment is a resident, working population. These are the people who keep the process going. A successful and a sustainable town needs successive generations to inhabit the shells of their predecessors and to create new shells. A working, forward looking and creative, multi-generational population is the one essential measure or yardstick of a living historic town. Without this vital element the historic town verges on, and many sink into becoming, a preserved open air museum.

Here then, in conservation terms, there is a tension between approaches, in decision making and in funding. In the conservation of historic towns and cities what should take priority, the conservation of the fabric of buildings and places or the fostering of economic and social conditions which facilitate continued human occupation. What are to be our priorities? Do we want living historic towns and cities where change takes place and where we risk losing buildings and spaces to retain communities? Do we want to retain fabric and risk the loss of communities? Are the two approaches mutually incompatible?

This is the challenge. It is time to make a radical reassessment of the way in which conservation is practised within the urban environment and it is time for a fundamental reassessment of priorities in future conservation and development strategies and spending.

This is the context within which historic urban conservation is operating. Now let us consider what conservation policies and approaches we apply. Let us look at what conservation tools we have, how they have evolved and how relevant they are now or are likely to be in the future.

\section{THE DEVELOPMENT OF CONSERVATION THEORY AND PRACTICE IN ENGLAND}

Conservation awareness and practice in England may be said to have developed via two routes and in response to two 
principal influences. First there was the late 19th century reaction, led by William Morris, to the practice of 'scraping' buildings, usually churches, back to a notional stylistic point in their past development and rubbing away all evidence of the work of later generations.

This reaction, formalised by the founding of the Society for the Protection of Ancient Buildings, established the essential conservation principle of respect for the integrity of the contribution which each period or stylistic addition makes to a building and indeed of respect for the 'patina of age' which a building gains through constant use over generations.

There was then, particularly in historic towns and urban areas, the establishment of an attitude of mind and subsequent conservation policy again founded on another reaction to circumstances, this time of a more dramatic and catastrophic nature. The bombing raids of the Second World War resulted in the loss of huge sections of the urban fabric on a dramatic scale. One result was the launch of a programme of rapid recording of buildings, details, structures and monuments, as records of our material culture in the face of impending loss. The second catastrophe, possibly even more damaging, was the wholesale, wanton destruction of historic fabric on a staggering scale as the result of the upsurge of prosperity and strident architectural fashion in the 1960's. Again there was a reaction and a tightening of approach. One result of this tightening was the creation of 'conservation areas', some of which are large enough to include the whole historic core of towns or cities'.

This is the provenance of our conservation thinking which has brought us to an approach which sees physical fabric as a repository of information about the past cultural and social activities of our society and has created an attitude to conservation which is motivated primarily by the containment or management of change and decay of the built fabric of bricks, stone, plaster, whole buildings or whole quarters of historic towns.

We have created for ourselves a situation where we are dominated by a fabric led approach to conservation. We think instinctively in terms of appropriate materials and restoration of original features, we view change with extreme caution, if not hostility, and we allow reuse only where it does not require change or alteration. New life must contort itself to fit functionally redundant spaces. What has this done to our historic towns, how well has conservation served them? ${ }^{2}$

\section{THE SUCCESS OF THE ESTABLISHED APPROACH?}

How has our approach worked in space and time? When applies to areas, such as historic towns, over long periods it might well be argued that we have created for ourselves a situation where buildings are becoming archaeologically preserved monuments, the buildings are islands floating in urban space which is interpreted only in terms of a setting without an intrinsic value of its own and where historic towns are becoming open air museums at odds with their domestic and commercial hinterland. We have been too conservative and too selective in our approach to urban conservation. First because we have lost sight of the matrix. We have concentrated almost exclusively on the buildings and neglected the historic qualities of urban space which connects one building to another, spatially and over time, and we have also, inexcusably, lost sight of the fact that historic towns are more than collections of buildings and spaces, they are the product of active communities. Flexibility towards the needs and the qualities of a resident community has too often been omitted from conservation thinking and strategy which is over dependent on a fabric led approach.

What have we produced? Have we been conserving towns or collections of objects? What is the situation which we now have to maintain and carry through into the next century? We have constructed a grossly artificial, and unsustainable, environment ${ }^{3}$. We have constructed a legislative and philosophical framework which has enabled us to promote, and enforce, an unrealistic retention rate of built fabric. In some cases, particularly in the cities of the once industrial north, we have ignored economic and demographic decline and we are rushing towards the ludicrous situation of maintaining the fabric of a city which no longer has a population to occupy it. We have maintained the fabric and crippled the process of urban creation.

\section{NEW ARTEFACTS AND A NEW APPROACH?}

Nor are we stopping here. We are extending the range of types and periods of buildings being included in the listing process and we are finding whole new classes of artefacts.

Post war buildings are now being considered for listing. Current controversies involving the listing of post World War II buildings are bringing the whole listing system into disrepute. Early in the 20th century the Royal Commission was interested in 18 th century buildings. It was not until after the War that there was interest in buildings before 1850 and with time the boundaries were expanded. By 1969 the system gave statutory protection to 120,000 buildings and recognition (not protection) to another 137,000 . Gradually with time the boundaries have been expanded to include more recent buildings. Now we have over 500,000 listed buildings and some 8,000 conservation areas in England alone and every year the list gets longer.

The listing system gives protection to:

- (a) all buildings before 1700;

- (b) most buildings 1700-1840;

- (c) buildings of definite quality 1840-1914;

- (d) selected buildings of high quality 1914-1939;

- (e) selected post WWII buildings.

The last category is where all the difficulties have arisen. Which buildings should be listed and who should decide? Some buildings, such as the National Theatre by Denis Lasdun, are quality buildings by famous architects yet they built in a particularly brutalistic architectural style. Others, 
such as the Gorbals council flats in Glasgow by Sir Basil Spence, are Modernist projects that seem now to be functionally obsolete and expensive to renovate. Others are minor, and not very good Modernist projects by famous architects that only art historians are interested in. Still others are badly built 1950's projects that cannot be easily readapted to current requirements. The public is often not very sympathetic to many of these Modernist projects.

The controversies involving the listing of post WWII buildings risk putting the whole system into disrepute in the eyes of the general public. Does the system exist for the good of the whole community whose general opinion is valued or is it a small elite of specialists and art historians who should decide in the name of the public good? Are the perceived architectural and planning errors of the brutally Modernist and insensitive architects of the 1950's and 1960's worthy of preservation? The difficult questions are endless. These controversies are another good reason to rethink current ways of listing buildings and designating conservation areas.

The listing system is itself being expanded. Over the past thirty years we have also become aware of the cultural importance of historic parks and gardens. Fuelled by the art historian lobby, the study was originally centred predominantly on the eighteenth century, aristocratic, country park. More recently the concept of historic, designed, space has been applied to towns and cities and we are increasingly aware of the cultural qualities of urban space in the form of public parks, town squares or cemeteries and even of street planting and design.

Urban greenspace, public and private, is an integral part of the historic town. Indeed, its fine grain and patterning comes in no small part from the way that local parks and private gardens have been made and used over time.

Like old buildings, parks and gardens also focus the memories of the community; like buildings they create a particular and recognisable resonance and also like buildings they acquire the patina of age. Conservation architects have to recognise that not only buildings but also spaces are important cultural objects of national importance. Urban spaces have been neglected and they may appear to be 'redundant' in that they are no longer used or furnished in the way they were at the end of the last or the beginning of this century. Yet a major public park is a structure with an integrity and a design rationale which cannot be ignored. A Victorian park may be in crisis, as many Victorian buildings are, but its historic and 'architectural' worth has to be respected as a cultural artefact in its own right and as a component which contributes to and describes the distinctive character of the historic urban environment.

An urban park, particularly a major one, does function as a piece of public architecture in much the same way as a building does. Many public parks have boundaries described by a polychrome and multi-textural composition of walls, decorative ironwork and substantial planting. This peripheral planting was carefully chosen and frequently designed to be massed in order to give directed views in and out of the park itself. Verticality comes from mature structural planting which creates a downward play of light and shade returned by lakes, ponds and fountains. Within this framework, space is structured and manipulated by path systems and plantings. Not all parks are the same. Some were designed as intensely formal compositions, others were, from the beginning, laid out in a more naturalistic style. Alongside the great parks there is also a great tumbling host of small parks, the work of local designers and borough and municipal engineers, which are just as important to local character and local leisure as the greater ones. The main point is that the parks are the result of a conscious design process which depends on buildings, landform and planting in equal measure.

Here then is a whole class of 'structures' which have, until recently, been left out of conservation thinking. Urban parks, cemeteries and spaces are as important as buildings in contributing to the particular qualities and character profile of historic towns.

What is our response? We have begun a listing process. English Heritage, a government organisation, is responsible for compiling a 'Register' of historic parks and gardens which lists and grades sites in a way similar to the listing of buildings ${ }^{4}$. At present the Register carries no statutory duties but this situation is itself fluid and developing and a move towards some form of legislative control seems inevitable. We are starting the whole process all over again ${ }^{5}$.

It is, of course, essential that there should be a 'list' or a record of cultural property; knowing the total population is fundamental to informed decision making. Are we, however, allowing the listing process to exert too great an influence? Has 'listing' in fact come to represent a limited and stagnating approach to conservation which measures success only in terms of buildings and fabric conserved? Is such an approach realistic? Can it be sustained or are circumstances changing and is this an appropriate time for a radical reassessment?

\section{A RADICAL REASSESSMENT}

It is perfectly reasonable that after thirty years of practice conservationists should be asked to audit and reassess their work, but more pressing than this is the potential, long term impact of 'sustainability'.

We are now, more than ever, charged with sustaining resources and land by the economic reuse and careful maintenance of existing buildings and indeed existing towns and cities. This looks like a boon for conservation, and it is, but not in the way that we have been used to.

We cannot simply go on conserving the physical materials of buildings and places. The older the original fabric becomes the more fragile it will be and the more costly to conserve; this is not sustainable. In some parts of this country we simply have too much. Our population is shrinking; our industrial base has shrunk and we have become over-en- 
dowed with 'built environment'. Conservation must seriously address the need to lose as well as retain structures and designed space.

However, much more important than all this is the need to regenerate our historic towns not in terms of fabric but in terms of community. If historic towns are to be sustained and sustainable then they must be places where multi generational resident communities can dwell. Conservation and the management of decay in buildings and spaces must merge with quality of life issues to sustain the contemporary community. The way in which we have practised building conservation within the urban environment has come perilously close to fracturing the wider structure of the town and has also come close to disenfranchising a whole generation of urban dwellers. Increased awareness of the historic qualities and values of urban space must not lead us in the same direction. We must acknowledge historic urban space and we must conserve some but we must not allow the growing appreciation of historic space as a cultural asset to fossilise yet greater chunks of urban environment. Conservation must develop and embrace strategies to facilitate fabric change to conserve communities.

\section{THOUGHTS FOR THE FUTURE}

There are already signs of dissatisfaction and a search for a new approach. Jones and Larkum have questioned the viability of continuing to designate yet more conservation areas. They have outlined a set of future directions ranging from 'designate and be damned' to removing all legislative controls and allowing market forces to set the pace of change ${ }^{6}$. $A$ very heated debate between planners and architects is just beginning. The Royal Institute of British Architects have started the debate and have drawn up a discussion document to promote radical changes in the planning system to facilitate new design and greater freedom of creativity. The Town Planning Institute has responded by accusing RIBA of "appalling architectural arrogance" . There are also signs of change in government thinking with PPG 15's acknowledgement that economic viability is a factor in planning for the conservation of buildings and sites.

How are these signs of dissatisfaction and a desire for change to be managed to create a positive response to the conservation of historic urban areas in the future? The answer is not to be found either in increasing legislative protection nor in dismantling the existing system. Rather, there should be a reassessment of conservation itself, as a process and as a profession and a redefinition of its role and place, its practices and objectives.

Conservation practitioners must stop being purely reactive and begin actively to participate in all phases of development projects. Those who wish to conserve the communities and spirit as well as the buildings of historic towns must accept that there will be change and must be prepared to work with property developers and the initiators of change. Conservation architects must learn to become involved from the beginning of the development process. It is here that special- ist knowledge, supported but not dominated by conservation legislation, can be used as a negotiating tool. Flexibility and subtlety in the application of legislation will lead the conservation process through to a more creative, dynamic and socially equitable direction in the future. The future of conservation, as well as the future of the historic fabric of towns and cities depends on a positive response from the architectural profession as a whole and particularly from the conservation architect.

\section{NOTES}

${ }^{1}$ In 1991 there were over 7,000 conservation areas in England, 350 in Wales and 550 in Scotland and they included over one million buildings. [Cullingworth, J. Barry and Nadin, Vincent, Town and Country Planning in Britain Routledge, London and New York, 1994 Eleventh Edition, p.160]. "Section 69 of the Planning (Listed Buildings and Conservation Areas) Act 1990 imposes a duty on local planning authorities to designate any 'areas of special architectural or historic interest the character or appearance of which it is desirable to preserve or enhance. There are now more than 8,000 conservation areas in England." Planning and Policy Guidance: Planning and the Historic Environment (PPG 15) p. 15 jointly issued by the Department of the Environment and the Department of National Heritage, September 1994.

${ }^{2}$ It is important to understand the difference between the terms conservation and preservation. "Preservation implies maintaining the original in an unchanged state and conservation embraces elements of change and even enhancement" [Cullingworth and Nadin (1994) p. 159]. This has been recognised in recent Government thinking, for example, when setting out a policy governing the approach to change of use of listed buildings PPG 15 (see below) states that "The Secretary of State (of the Department of the Environment) is not generally in favour of tightening development controls over changes of use as a specific instrument of conservation policy. He considers that, in general, the same provisions on change of use should apply to historic buildings as to all others." [PPG15 p.5-6]. Thus conservation implies change and the search for new viable uses for listed buildings.

${ }^{3}$ A 1992 report of English Heritage showed that 7\% of listed buildings were at risk because of neglect and that a further $14 \%$ needed repairs so as to prevent them falling into the 'at risk' category.[EH (1992), p.11 as quoted in Cullingworth and Nadin (1994) p. 161]

The listing of buildings has two main objectives:

(a) guidance; to provide guidance to local authorities in their planning functions; they will take into consideration the listed buildings in an area for which they are preparing a development plan;

(b) protection: when a building is listed the owner must obtain permission (listed building consent) from the local authority before undertaking any demolition or alteration work on the building; [Cullingworth and Nadin (1994) p.158].

${ }^{4}$ National Heritage Act of 1983 empowered English Heritage to compile a register of gardens and land of special historic interest. A definition of the aims and an outline of criteria for grading sites is set out at the beginning of each of the county volumes of the Register. No additional statutory duties arise from inclusion on the Register.

${ }^{5}$ For a discussion of the response of planners to historic parks and gardens see; Stacey, Mary Sabina, The Protection of Historic Parks and Gardens in the Planning System, Town and Country Working Paper No. 29, The Faculty of the Built Environment, University in the West of England, Bristol. (1993) 
${ }^{6}$ Larkum, Peter J. and Jones, Andrew N., 'Conservation areas: where will it all end, 'Paper presented at the Royal Town Planning Institute Conference "Conservation areas: an outdated institution" held at York, U.K. December 1994.

7 Building Design No 1225, June16 1995

${ }^{8}$ Indeed the legislation underlines the fact that the planning system must "take account of the Government's objective of promoting sustainable economic growth, and make provision for development to meet the economic and social needs of the community. " [PPG 15(1994) p.1]. PPG 15 also points out that historic buildings must have economically viable uses in order to survive and this often requires them to be readapted. This implies finding the "optimum viable use that is compatible with the fabric, interior and setting of the historic building" [PPG 15(1994) p.9]. That conservation and sustainable economic growth are complementary objectives has been accepted by the Government and is embodied in, This Common Inheritance, Britain's Environmental Strategy. HMSO, London 1990.

Ken Hampson B.Sc.(Arch.), B.Arch., M.A., Canadian architect interested in old buildings, conservation and urban regeneration.

Judith Roberts B.A., M. A. Ph.D., Research Fellow, Institute of Advanced Architectural Studies, The University of York (From August 1995, Senior Research Fellow, De Montfort University, Leicester) 